\title{
THE CHOICE OF FOREIGN LEGAL TRANSPLANTS POLICY IN REGULATING INDONESIAN COPYRIGHT LAW: BETWEEN STANDARDIZATION AND COAGULATION
}

\author{
O.K. Saidin* \\ Department of Private Law in Intellectual Property Rights Subjects, Faculty of Law, \\ University of North Sumatera, Medan \\ Jalan Universitas No. 4 - Kampus USU, Medan, Sumatera Utara 20155
}

\begin{abstract}
Any legal development shall be coming along with the development of civilization. Building the whole society to be more civilized-to live by the standardized customs, religions and in accordance with any cultural values to be well-institutionalized normatively in the life of people. The standardization of law in normative form is to adopt legal policy of law transplantation deriving from foreign tradition and culture to be transplanted into model of law in home country. Quite often, such legal transplantation is not effective to be implemented. In the case of Indonesian copyright, the law which was before standardized eventually becomes coagulated.
\end{abstract}

Keywords: legal transplants, copyright, legal policy.

\section{Intisari}

Pembangunan hukum sebenarnya adalah pembangunan peradaban. Membangun masyarakat agar bisa hidup beradab. Hidup dengan standar adat istiadat, kebiasaan, moral, religius dan nilai-nilai kultur yang dibakukan secara normatif. Pembakuan hukum dalam bentuk normatif dengan memilih politik hukum transplantasi adalah memilih model hukum yang berasal dari kultur atau budaya asing untuk dicangkokkan menjadi model hukum di negeri sendiri. Kerap kali hukum hasil pencangkokkan itu tak cukup efektif untuk diterapkan. Dalam kasus transplantasi undang-undang hak cipta Indonesia, hukum yang semula dibakukan akhirnya menjadi hukum yang dibekukan.

Kata Kunci: transplantasi hukum, hak cipta, politik hukum.

\section{Pokok Muatan}

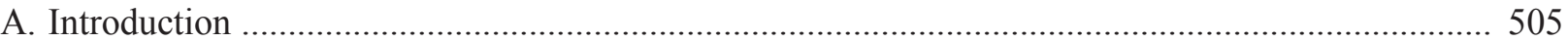

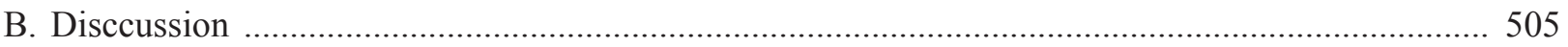

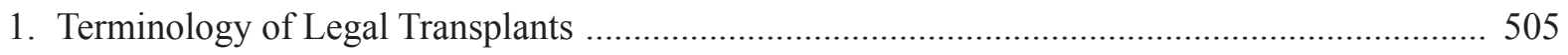

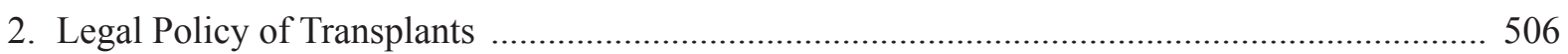

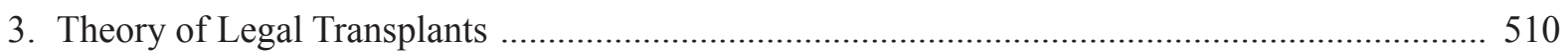

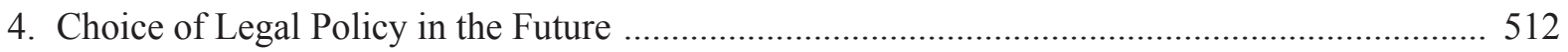

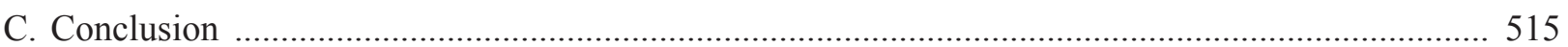




\section{A. Introduction}

Indonesian Copyright Law No. 28 of 2014

has been the very result of legal transplantation of foreign legal system to be transplanted into Indonesian legal system (Indonesian Copyright Law). Initially, it was related to Auteurswet 1912 Staatblad No. 600, then the wet was uprooted and substituted with Law No. 6 of 1982. The law was then finally changed to Law No. 7 of 1987. Along with its enactment, the Law No. 7 of 1987 was changed to Law No. 12 of 1997. In later stage, the Law No. 12 of 1997 was then changed to Law No. 19 of 2002 and then changed to Law No. 28 of 2014. In the period of 20 years, Indoneisan Copyrights Law has to experience changes - during the period of independence - as matter of fact, the ex-collonial law of Auteurswet Staatblad 1912 No. 600 could stand the test of time for as long as 70 years. The policy of legal changes on copyrights law was done by the choice of legal transplant. Legal policy is done by adopting foreign law to be transplanted as a binding law in home country. It is a legal policy that is covering the making of legal materials as a basic policy and the implementation of its legal norms in the society. Quite often, such a choice of legal policy just did not consider the aspects of legal culture and very often falling the way side the phylosophical-ideological setting of the state and nation, which is fully basis for legal development within the national system. Should this becomes a choice, the legal transplants of foreign law must not be falling the way side of the framework of Indonesian national system (Sub-system politics, economic, culture, social, security and justice, etc.). Expectation, ideas and thoughts that are filled and characterized to be Indonesian culture or the original paradigmatic value of Indonesian culture and society that is formed asbtractly as pancasila's values. Those values must be the base of the choice of foreign legal transplants policy in regulating indonesian copyright law.

\section{B. Disccussion}

\section{Terminology of Legal Transplants}

Legal transplants ${ }^{1}$ or legal borrowing, or legal adoption are the terms introduced by Alan Watson, ${ }^{2}$ to refer to a process of borrowing or adopting or translocation of law from one place or a country or a nation then the law is implemented in a new place to be mingled altogether with with the prevailing laws that exist long before the one comes.

Quoting Esin Orucu, ${ }^{3}$ Alan Watson came to a conclusion: "Legal transplant still persists and will go on prevailing well just as in the era of of Hammurabi. Further Esin Orucu stated:

What is regarded today as the theory of 'competing legal systems', albeit used

\footnotetext{
Terminology of Law (rechts terminologie) on legal transplant is used by legal experts to refer to policy of a state, namely a making use of foreign law to be used in home-country. So far, there are many terms used to describe such things ranging from terms of borrowing foreign law, adoption of law, migration of law, translocation of law to the terms of colonization of foreign law and some use the term of occulation of law. Just to mention the term of legal receptions as promoted by Loukas A. Mistelis and Moh. Koesnoe, legal borrowing or legal adoption as promoted by Alan Watson who before he came to use the term of legal transplants. Legal migration is used by Katharina Pistor, legal colonization is the term used by Galanter, translocation of law ini is introduced by Antony Allott, legal surgery is the term promoted by Loukas A. Mistelis, legal transposition is promoted by Esin Orucu, legal change is promoted by Haim H. Cohn. See Julius Stone, 1983, Legal Change Essays in Honour of Julius Stone, Blackshield, Butterworths Pty Limited, Australia, p. 56. Even Roscoe Pound ever used the term "assimilation of materials from outside of the law", to refer to a series of process of legal transplants. Further, see Tri Budiyoni, 2009, Legal Transplants of harmonization and Potentials of Conflict: Transplant Study of Doctrines Developved by Common Law Tradition on UU PT, Griya Media, Salatiga, p. 124, p. 4. Professor of Legal Scient from Delf Universiteit by the name Mr. W. C. Van Den Berg who also was the advisor for Oriental Languages and Islamic Law during the administration of the East Indies. He ever researched customary law in Indonesia and promoted a well known teory so called "Receptio in Complexu". Even this one still uses the term Islamic legal transplant (relegious law) into customary law. Even Berg said, all Islamic Laws were received by customary law. Unless otherwise in contrary with the original teachings, Berg said, the indigenous law would come along with the religious law p even if he changed his eligion, he would follow the law of his religion faithfully. See Sajuti Thalib, 1987, New Legal Policy on the Position and Roles of Islamic Law in the National Legal Building, Binacipta, Bandung, p. 51. However, this opinion was opposed by Hazairin, he insisted that not all customary laws were transplanted from Islamic laws, see further Hazairin, 1985, Seven Series of Law, Bina Aksara, Jakarta, p. 44. More importantly, Berg used the terms receptions for the term of legal transplants.

Alan Watson, 1974, Legal Transplants an Approach to Comparative Law, Scottish Academic Press, America, p. 22. By borrowing the opinion introduced by Roscoe, Pound Watson wrote "[...]" and Roscoe Pound could write: "History of a system of law is largely a history of borrowings of legal materials from other legal systems and of assimilation of materials from outside of the law", compare with Tri Budiyoni, Ibid., p. 25. See also Gunawan Widjaja, 2008, Transplants of Trusts in Civil Code, KUHD and Indonesian Stock Market Law, Rajawali, Jakarta, pp. 35-38.

Alan Watson, Op.cit., p. 5.
} 
mainly in the rhetoric of 'law and economics' analysis, was the basis of the reception of laws that formed the Turkish legal system in the years 1924 - 1930. The various Codes were chosen from what were seen to be 'the best' in their field for various reasons. No single legal system served as the model. The choice was driven in some cases by the perceived prestige of the model, in some by efficiency and in others by chance. ${ }^{4}$

Orucu, an Emeritus Professor of Comparrative Law at the University of Glasgow, UK, Erasmus University, Rotterm - Netherlands Lat at Yetipede University, Istanbul-Turkey, came to a conclusion that there was not any single legal system used as a model in many countries. By taking an example from the people of Turkey, Orucu further explained that Turkey, in the aftermath of the fall of Ostmanian's dynasty, has taken up many legal system to be used as a model of legal development in its home country. Criminal and Civil law were taken from Switzerland and the state administration law was taken from French. By choosing variousl legal model, through the policy of transplants, Orucu said, Turkey under the regime of Mustafa Kemal Al-Taturk, had succeded to lay down the transplant legal politik to become a tool of cultural legitimacy, because in the end, the legal model chosen was not entirely tied to one of the dominant cultures.

In the case of Indonesia, adopting a foreign legal system to be developed as a legal system in home country, is not of a new issue. The principles of corcordance that was chosen as Indonesian legal policy during the era of Netherlands East Indies and continued to be developed in the era of independence is the best example that has given us confidence that adopting foreign legal system to be used in our home country is of the commonly acceptable fact - and too bad things to do. What is so called legal transplants continues to avail ever since the pre-Netherland's colonial era to the present, ${ }^{5}$ from changing the position of original Indonesian law (customary and indigenous tradition) until the situation of the coming of the totally new legal principles - that has never been recognized in the civilization of law of Indonesian.

Similarly with the success of Indonesia in producing the Copyrights Law, later recognized as Law No. 28 of 2014, through a policy of transplants as to be adjusted to the demand of globalization era. At least, Indonesia has got a legal tool on copyrights that meets international standard - a standard introduced by GATT/WTO of 1994 as set forth within TRIPs Agreement, regardless of many criticisms addressed to it. The success in area of legislation has never been in compliance with the success that follows in later stage, mainly in terms of its substances and enforcement. As a matter of fact, the said law is totally failing to achieve its real goals - a failure to formulate ideas and aspirations of the State, and a failure to create a certainty of law and even a failure to achieve the ideas of welfares through optimum protection over pieces of work. In a simple term, the adoption of legal transplantation has totally failed in transforming phylosophical and ideological basis of Pancasila into the formulation of the National Law on Copyrights. The influence of foreign ideology/philosophy has come spoil this law. Legal experts have failed to use Pancasila as a "filtering" ideology when the policy of legal transplants was taken in the formulation of Law on Copyrights. This has not been done once, but several times recurring along the history of legal changes of Copyrights Law.

\section{Legal Policy of Transplants}

Harold J. Laski confirmed a basic state policy, which is translated into the forms of rules and regulation, is said of legal policy. ${ }^{6}$ Legal content (borrowing the terms used by Lawrence Friedman,

Alan Watson, 2006, Legal Transplants and European Private Law, University of Belgrade School of Law, Pravni Fakultet, Belgrade, pp. 6-7. See also Esin Orucu, 2004, The Enigma of Comparative Law, Martinus Nijhoff Publishers, Leiden/Boston. See also Esin Orucu, 1996, Studies in Legal Systems: Mixed and Mixing, Kluwer Law International, London/Boston, p. 26.

In the era of Hindish, the law of Hindish was also stained the legal relations that enforced in the society in Indonesia that time, also when Islam was brought in to Indonesia, the law of Islam was also stained the legal development that time. So that it was indeed true what Roscoe Pound has said, the history of legal system was the history that borrowed and assimilated the legal material from another legal material.

6 Harold J. Laski, 2010, Studies in Law and Politics, Transaction Publisher, London, p. 125. 
legal substances) as produced by legislative body is really the product of legal policy. To which direction the law is directed, as Padmo Wahyono quoted, is of legal policy. ${ }^{7}$

Hikmanto Juwana more concisely mentioned the legal policy, which are "several objectives and reasons that become the basis of the formulation of laws. The objectives of law whether they were meant to create justice, certainty of law or any benefits to achieve are said as the steps of legal policy. Why the rule and regulation is formed and why is the content to be made so, and for what objectives the rules and regulation created are all said as legal policy, as suggested by. ${ }^{8}$ Therefore, according to him, a legal policy does not rest at the moment of its formulation as a basic policy, but at the time of its enactment policy. There is a "bridge" connecting between both and between both there should be close correlation and coordination - in order to achieve the efforts of the objectives of essentially well defined legal policy for furthering policy goals. It is for such a reason, the existence of law should be seen in a system. Law cannot be seen partially in context of social and national system. The later opinion is introduced by M. Solly Lubis in lecturing activities within the University of North Sumatra and is understood as a theory of legal policy as the theory of National System. The laws that are produced and implemented may not falling the way side of the framework of a national system - not to be falling the way side of the nation's identity not to be falling the way side of the philosophical and ideological basis of the nation and state and all legal products being produced should refer to the original paradigmatic values of Indonesia cultures and societies. It is for such a reason, the law in the theory of M. Solly Lubis needs to be placed as a part of a political sub-system in context of a national system. According to him, all laws whether it may be the time of its formulation (basic policy) or its implementations (enactment policy) are influenced by non-legal factors (as a sub-system) within the national system. Law is the product of politics - the results of political power, M. Solly Lubis further mentioned.

Simply, M. Solly Lubis described the legal position as a sub-system within Indonesian political system in the following scheme:

Scheme 1.

The Scheme National Legal System Development (NLSD)

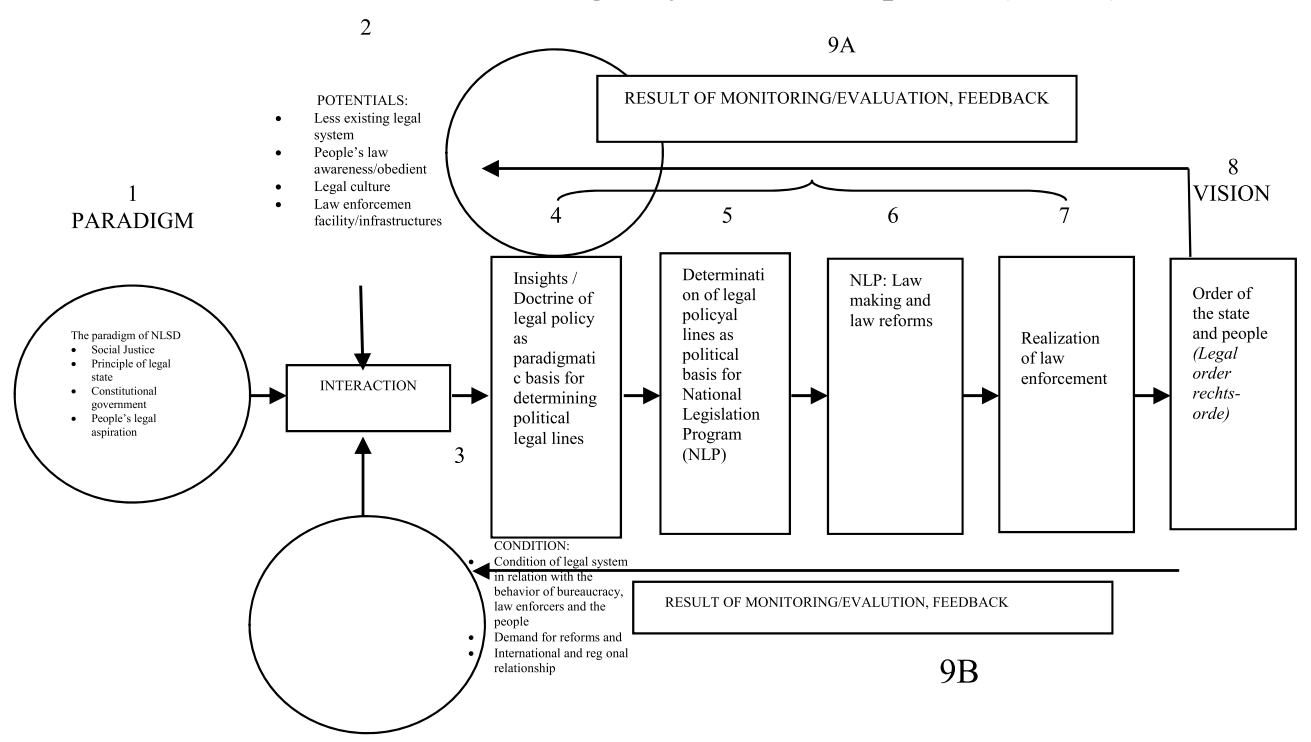

Source: M. Solly Lubis, 2011.

Padmo Wahjono, 1983, Indonesia Negara Berdasarkan Atas Hukum, Ghalia Indonesia, Jakarta, p. 160.

Hikmahanto Juwana, "Politik Hukum Undang-Undang Bidang Hukum Ekonomi di Indonesia", Jurnal Hukum, Vol. 01, No. 1, 2005. At least based on the explanation of Hikmahanto Juwana, there were two important as the reasons why legal policy is necessary; first, the reason why the formulation of a legislation is necessary; second was to appoint what to translate into legal sentence in the formulation of Articles in the Acts. 
Legal policy actually encompasses the whole process of law, either in the moment of the making or the moment of implementation. Even when the law is implemented the progress and achievement are evaluated in order to get feedbacks for perfectness of the norms for the same of the future time. Then, the new strategy is found to formulate further legal norms (basic policy) as well as the strategy for its implementation (enactment policy).

As a result of political power, any law contains the political power of the rulers. Why the law of copyrights is produced (basic policy), what internal and external conditions are actually being faced (basic policy) and why the entailing articles saying so? When it is to be placed within the framework of national system, based on theory of National System developed by M. Solly Lubis, during which time the copyrights law was produced (basic policy), what external and internal situation were Indonesia facing? The situations were examined according to the ideological factors, economy, socio-culture and security and defense. What constructive and destructive effects that later on excelled after that policy was taken. At the level of its implementation (enactment policy), it can be examined by way of this theory of National System - the level of quality of the national security of Republic of Indonesia by measuring the effectivity of the natonal law of copyrights. The above explanation, if it is correlated to the scheme developed by $\mathrm{M}$. Solly Lubis in his book: "Strategic Management of Legal Development," will strengthen the said National System Theory that he introduced. See, the following scheme:

\section{Scheme 2.}

\section{The Scheme of Indonesian Political System (INDOPOLS) by Systemic Analysis}

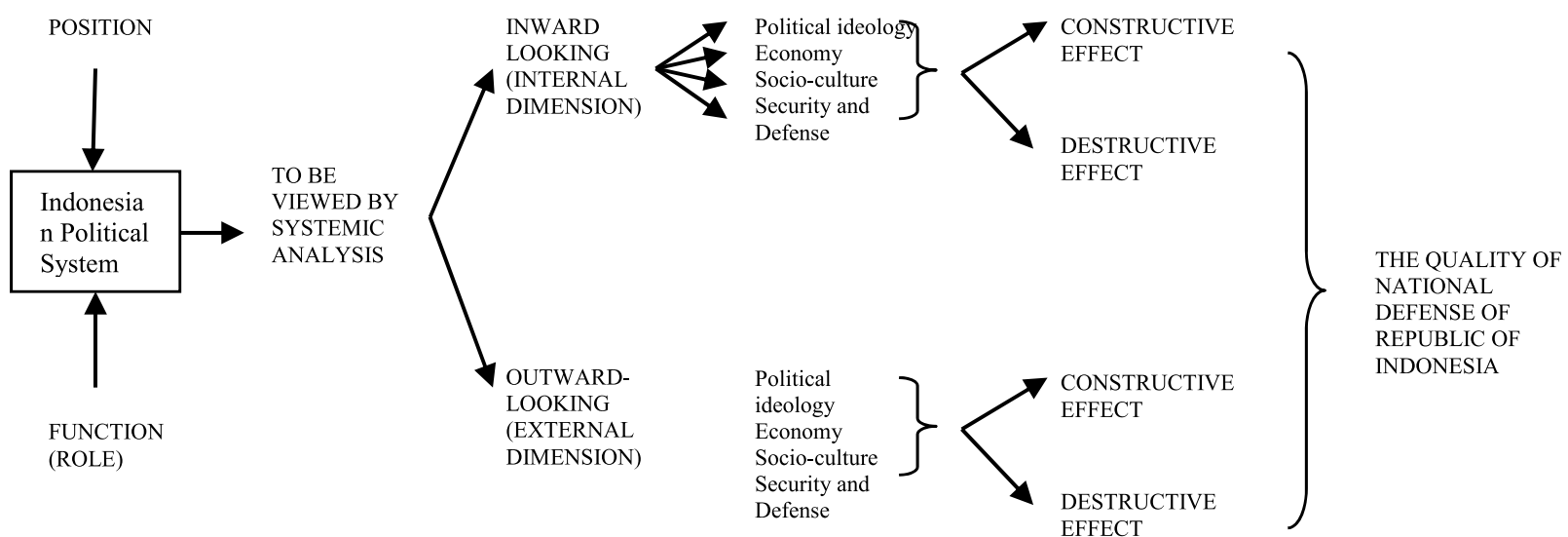

Source: M. Solly Lubis, Lecturing material in the Doctoral Program on Legal Science at the Law Faculty of Universitas Sumatera Utara.

Notes:

1. INDOPOLS encompassed one of susb-systems within a framework of national system.

2. Legal policy is one of the subsystems within national political system.

3. This means that the quality of "legal policy" will certainly and decisively determine the quality of political system, as also to determine the quality of national system.

4. This also means that the quality of legal policy is the determinant for the level of national security.

The above scheme describes the necessity to place the National Legal Development System within the framework of a national system, by referring to political policy framework using of the national copyrights law is found, then the systemic approach based on the strategic conceptual perspectives.

Soon after the effective level of enforcement

M. Solly Lubis, 2011, Manajemen Strategis Pembangunan Hukum, Mandar Maju, Bandung, p. 127. Compared with the opinion from Moh. Mahfud M.D., that legal policy was as a whole process of the making and implementation of law, to what direction the law will be built or enforced, Moh. Mahfud MD, 2009, Politik Hukum di Indonesia, Rajawali Pers, Jakarta, p. 54. 
finding is used as a feedback for the formulation of concepts (legal policy) of the new national copyrights law by still considering all of the nonlegal aspects surrounding the policy and by placing it within the national system.

What legal policy to take and develop further next is what to formulate as something new. This cycle will move and roll on - round and round again as along as this country still exist and any laws produced therein will not fall the way side of the "path" of the framework of national system? This is what more or less the ideas developed by M. Solly Lubis through his respected theory of National System.

Further, in order to sharpen the systemic analysis based on this National system, another scheme is presented to show correlation between the theorists and the practitioners in the efforts of legal building like the following:

Scheme 3.

The Scheme for Cooperation between Theorist and Practitioners in the Efforts of Legal Building

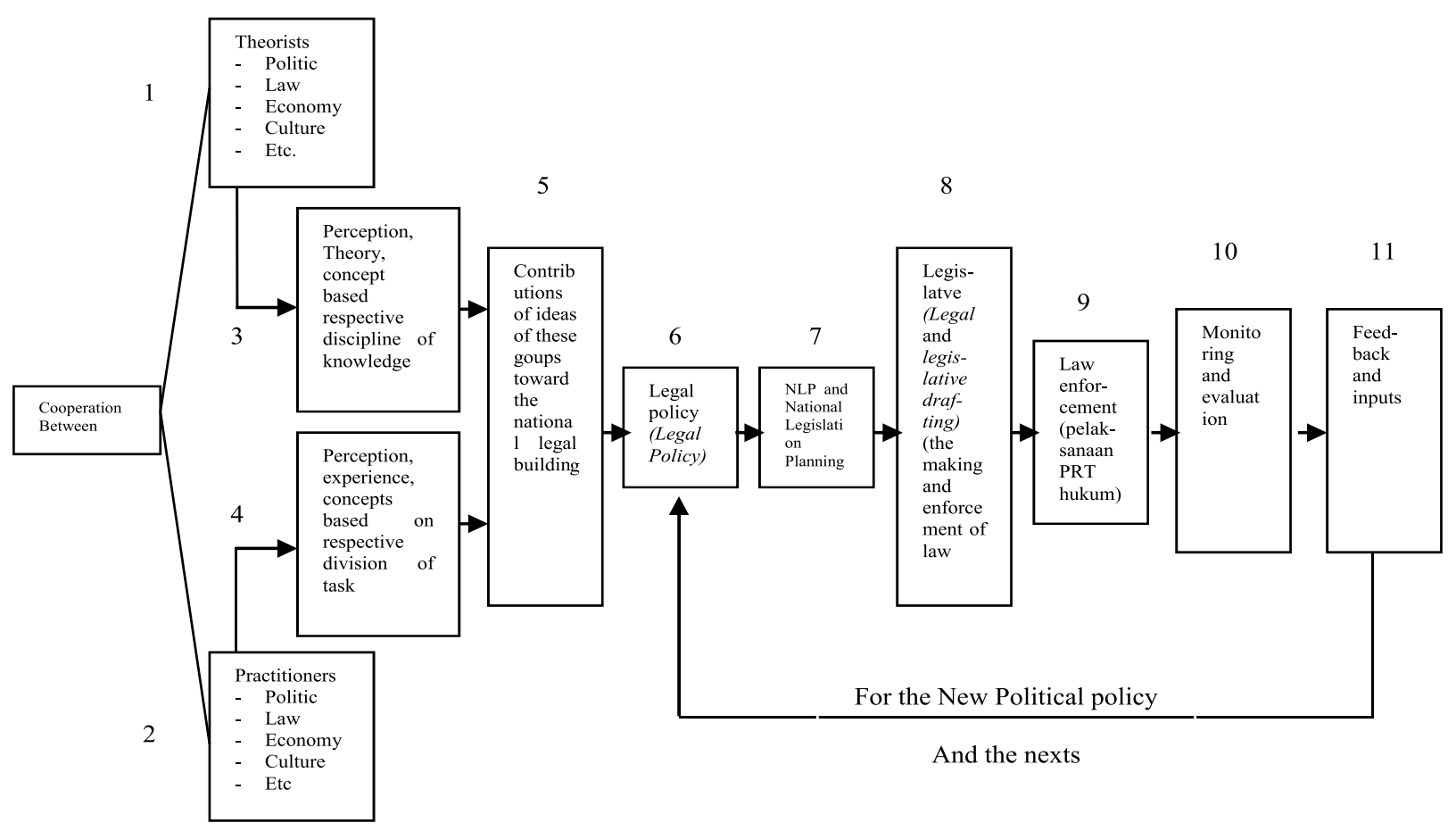

Sourse: M. Solly Lubis, 2011.

Accoding to M. Solly Lubis, a cooperation is needed between the theorists and the practitioners. This is meant to bridge between theoretical concepts laid out on papers and the empirical experience owned by practitioners, most especially when the law is implemented in the field. Theoritical perspectives and practical experiences would all lead to producing new concepts with new thoughts that can be contributed to better performance of the national legal building (national legislation program and national legislation planning), which conducts activities to prepare the formulation of regulation as legal policy.

The results made by national legislation institution would produce regulations, which then be implemented in the middle of society. The enactment is then monitored and values again by the theorists (academicians) after hearing empirical experience of the practitioners. The results of monitoring is someday made to be a feedback to formulate and produce new legal policies. 


\section{Theory of Legal Transplants}

The policy of a state may refer to a certain format of other nations. The development of economy or education of our country may imitate models as developed by other nations. However, it does not necessarily and fully apply in context of legal development. The theory proposed by Robert B. Seideman ${ }^{10}$ that is The Law of Non Transferability of Law concluded that the law of a nation cannot be taken up all the way it is - without having to include several surrounding aspects (socio-cultural aspects) in the place where the law belongs.

This theory was in fact formulated from the results of Seidemen's research together with his friend William J. Chambliss in a country in South Africa the ex-British collony. Soon after the British left the country, the Biritish law that was left could not run its functions, which was due to the South African socio-cultural factors that differed from those of the British socio-cultural aspects. Similarly, in other places like Turkey, Etiopia and the ex-French collonies in Africa and Indonesia, the foreign laws were successfully transplanted in terms of the substances - however they failed in terms of the implementattion, which were due to different factors in context of socio-economic and politic aspects and other other subjective factors, such as tradition of the local indigenous people.

For the case in Indonesia by modifying a little bit from what was written by Seidman, the pulling power in the legal policy process (either in basic policy structure or in the enactment policy structure) Indonesian copyright law can be shown in this following scheme:

\section{Scheme 4.}

\section{Legal Policy Process (Basic Policy and Enactment Policy) Indonesian Copyright Law}

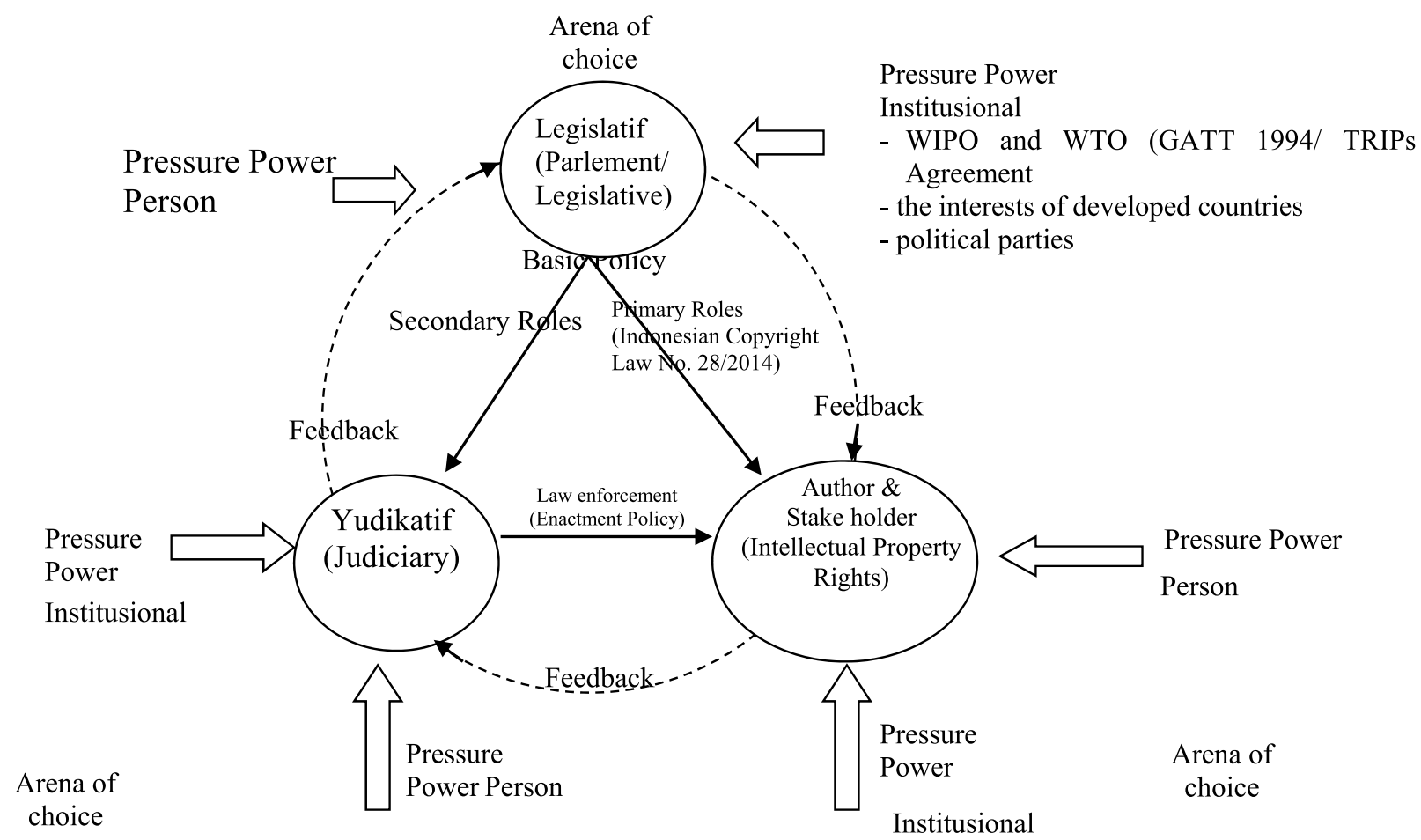

Source: O.K. Saidin, 2013.

10 Robert B. Seidman, 1978, The State, Law and Development, St. Martin's Press, New York, p. 29 
In various countries, the following factors like; geography, history and the advancement of technology would adequately influence the failure of law enactment, from which the norms have been derived from foreign law as stated by Robert B. Seidman and Ann Seidman:

Turkey copied French law, Ethiopia copied Swiss law, the French speaking African colonies, French law, Indonesia, Dutch law. Universally, these laws failed to induce behavior in their new habitats anything like that in their birtplaces. Inevitably, people chose how to behave, not only in response to the law, but also to social, economic, political, physical and subjective factors arising in their own countries from custom, geography, history, technology and other, non-legal circumstances. ${ }^{11}$

Refering to the opinions stated above, it is about time for Indonesia, in its policy of legal development, to pay great attention and to reconsider socio-cultural factors, for when one is borrowing the term used by Satipto Raharjo, the does not merely exist in a vacuum room, but it exists together and along with other social subsystem, in wider social system. M. Solly Lubis also confirmed that the law is only one of the existing subsystems within a national system. The future of the law itself is significantly determined by the choice of legal policies. $^{12}$

The formulation of law materials (substantive aspects, as Friedman said) by legislative bodies is not of free value of external influences. Legislatures in the way they run legislative function, shall receive outside influences - either as an in stitution or as an individual. Similarly in terms of process of the law enforcement, even the appartuses of the judicative are not free-value of any factors as experienced by the legislatives. In then end, the produced law is always formulated as a resultant of the overarching powers. Similar opinion was also mentioned by Harold J. Laski, explaining that in the end, the commonly used law in the society was the one produced as a result of the overarching powers as political interests, either by the time it was produced or by the time it was enacted or implemented.

Specific in a case of copyright law, the Law No. 28 of 2014 on Copyrights, was a resultant of the overarching powers either internally or externally within the state's institutions (homecountry and internatioal pressures) or the internal and external influences of the legislative and the judicative within the homecountry - either institutionally or individually.

The opinion proposed by Robert B. Seidman and Laski, when it is correlated to the existence of law in the present Indonesia, one may come to a conclusion that thefinal results of law being enacted in the middle of our society has been the resultants of the overarching powers (intra-vectors) of each the influencing factors (political and non-political). ${ }^{13}$

The international pressuring factors (economy and politic) has been one factor that become a political power in shaping the Law on Copyrights. The position of Indonesia in the membership of the General Agreement on Tariff and Trade (GATT) 1994/World Trade Organization (WTO), has required Indonesia to ratify the results of the rounds of the General Agreement on Tariff and Trade (GATT) 1994/World Trade Organization (WTO), where one of the goals of the agreement is related to legal instrument of the TRIPs (The Agreement on Trade Related Aspects of Intellectual Property

11 See further Ann Seidman dan Robert B. Seidman, 1994, State and Law in The Development Process Problem-Solving and Institutional Change in the Third World, St. Martin's Press, New York, p. 44.

12 See further Satjipto Raharjo, 2009, Negara Hukum yang Membahagiakan Rakyatnya, Genta Publishing, Jakarta, p. 45. See further Satjipto Raharjo, 2009, Hukum Progresif Sebuah Sintesa Hukum Indonesia, Genta Publishing, Jakarta, p. 58. Also compare Satjipto Rahardjo, 2009, Membangun dan Merombak Hukum Indonesia Sebuah Pendekatan Lintas Disiplin, Genta Publishing, Yogyakarta, p. 62 and M. Solly Lubis SH, 2002, Sistem Nasional, Mandar Maju, Bandung, p. 71. Compare with the opinion from M. Solly Lubis which placed law in legal policy together with another national sub system in one system which was called SISNAS by him. M. Solly Lubis, 2011, Serba Serbi Politik \& Hukum, Softmedia, Jakarta, p. 65.

13 Compare with the opinion of Harold J. Laski, 2009, Studies in Law and Politic, Transaction Publisher, New Jersey, p. 68, that the pulling power one sided in legal policy, would effect the result of law formulation. Also see (economy and law) Robert Cooter and Thomas Ulen, 1997, Law and Economic, Wesley Educational Publishers Inc., California. See also Eric A. Posner, 2000, Law and Economics, Foundation Press, New York, p. 155. 
Rights). In his essay, Ganguli further stated:

The TRIPs agreement provides considerable room for its Members to implement the provisions and achieve a proper balance of various domestic/national interest. ${ }^{14}$

Its consequence in the area of the protection of Intelectual Property Rights, The Agreement on Trade Related Aspects of Intellectual Property Rights Convention, as one of goals within the rounds of the General Agreement on Tariff and Trade (GATT) 1994/World Trade Organization (WTO), along with the following coventions, such as Bern Convention dan Rome Convention (1961) are obligatory to be ratified. Soon after Indonesia has ratified the GATT/ WTO 1994, through Law No. 7 of 1994, Indonesia has been officially and legally tied (morally also of course) to that binding international agreement. Consequently, Indonesia should make proper adjustment to its law of Inteletual Property Rights to be in compliance with the international conventions. This is what has put Indonesia in state of revising its law of the Intelectual Property Rights several times, including that of its law of copyrights.

\section{Choice of Legal Policy in the Future}

Great precaution in the conduct of foreign legal transplants to be embedded into Indonesian law in the area of the Intelectual Property Rights has been launched by Candra Irawan and Budi Agus Riswandi. Some of the following are excerpts from their opinions: ${ }^{15}$

1) Indonesia should more carefull in adopting The Agreement on Trade Related Aspect of Intellectual Property Rights (TRIPs) into the law of intellectual property rights.

2) Should a legal transplants is of necessity, the national interest should be prioritized.

3) There was a forced impression in the adjustment of the law on the intellectual property rights to be fully in compliance with the The Agreement on Trade Related Aspect of Intellectual
Property Rights.

4) The aspects of national interests were not obviously seen in the process of the said legal transplants, despite the national interests were brought altogether as considerants. However, the real norms or souls were not clearly reflected (as ideological and philosophical basis) as an Indonesianbound soul.

5) Foreign interests have significantly been promoted so that the law of the intellectual property rights just does not reflect our national interests.

6) Culturally, the Indonesian livil model is of communalistic and not of individualistic, The Agreement on Trade Related Aspect of Intellectual Property Rights apparently promotes individualistic cultre, which is of very contrary to the culture of Indonesian life.

When the results of the legal transplants is enacted, it accepts so much criticism and controversions. In the area of cinematographic work protection, the law is not able or not adequately effective to protect the producers. Ideally, when the law is completely formulated and ready for enactment, it could have been implemented and is effective to achieve the goals. Cinematographic work is one of the creation (among 12 creations) to be protected by the national copyrights law. The cinematographic work encompasses within it not only the work or art and literatures, but also includes the field of science. Cinematographic work in documentary film and any coverage about natural phenomena, the activities of living things and the earth's activities and of other planets, have a lot to show visually. In short, cinematographic work combines the aspects of art and literatures, either the sequence of stories quoted from novel, songs or music performed - until the artistic arrangement, they are all well combined in the work cinematography. In other words, cinematography

\footnotetext{
14 See further Prabuddha Ganguli, 2001, Intellectual Property Rights Unleashing the Knowledge Economy, Tata McGraw- Hill Publishing Company Limited, New Delhi, p. 59.

15 See further Candra Irawan, 2001, Politik Hukum Hak Kekayaan Intelektual Indonesia, Mandar Maju, Bandung, pp. 14-22.
} 
covers all of the legal objects to be protected by the law of copyrights, ranging from sciences, and art to literatures. $^{16}$

The legal transplants of the foreign law has manifested in the form of national copyrights law No. 28 of 2014. The said law has been implemented across Indonesia territory - from Aceh until Papua. The enactment of the national copyrights law has left countless notes, most especially in the protection of cinematographic work.

Soon after the national Copyrights Law No. 28 of 2014 was enacted, Indonesia would seem to have legal instrument equally perfect like other advanced countries. In other words, in the event that when a foreign investment enter Indonesia requiring proper protection over the foreign copyrights, juridically Indonesia would not anymore seem to experience uncessary difficulty, which would mean that the standard of copyrights protection in Indonesia should have been equally the same as of those advanced countries of the world, for according to Candra Irawan, ${ }^{17}$ Indonesia does not only fulfill the minimum standart set forth by the General Agreement on Tariff and Trade (GATT) 1994/World Trade Organization (WTO), but also to fulfill optimum requirements as set forth thereof.

However, the achievement of legislative institution in producing the national copyrights law is worth appreciating, for whatever it is amid its limitation, the said institution has worked to produce such a legal instrument despite its being not-perfect emprically in terms of its full implementation, which is not yet very effective. Just mention a few among other, the hijacking of the cinematographic work in the form of Video Compact Disck, which makes the DVD, as found in many stalls in Medan city, comes in in lower price ranging from Rp. 3.000 - Rp. 5.000 per piece. As a matter of fact, the same item when bought in DVD shops in Singapore the price may come in 7 until 10 Singaporean dollars or it is equivalent to Rp60.000 until Rp70.000 of Indonesian rupiahs per piece. This has been showing that such item is sold in a very bottom-rock price in traditional and modern market in Medan city. This is happening so because the item is produced without paying royalties to the producers and the creators or the right holder of the said cinematographic work. ${ }^{18}$

The consumers themselves just cannot be blamed and do not necesarily mean that they do not understand the rules. The DVDs themselves are marketed by way of the "the demand law" of the market. Where there is the cheaper price availavle is where the consumers are going. The Indonesian culture is not yet accustomed to giving protection model as mandated by the national copyright las No. 28 of 2014. To be measured from the effectivity of the enactment of copyrights law No. 28 of 2014, in the middle of our society, it can be assumed that the effectivity of venactment of the copyright laws, most especially in context of the protection of cinematographic work, is remaining very low.

The fourth problem deals with the impact of globalization towards the copyright law itself. The globalization has brought impacts many countries of the world to come in with choices of legal policy of transplants of law. Ratifying the TRIPs Aggrement is a consequence of the results of the Uruguay Round that produced the General Agreement on Tariff and Trade (GATT) 1994/World Trade Organization (WTO), which is of lehal policy choice being taken by Indonesia, as an impact of the economic globalization. This legal policy choice also has brought impacts upon the existence of law (the National Copyrights Law).

Copyright which includes science, literary arts as well as cinematography does not grow linearly from the East to the West flow, but it grows sporadically in various parts of the world. It has been

16 See further O.K. Saidin, 2013, Aspek Hukum Hak Kekayaan Intelektual (Intellectual Property Rights), RajaGrafindo Persada, Jakarta, p. 54.

17 See further Candra Irawan, Op.cit., p. 316. He said that the adoption of the TRIPs into Indonesian Intellectual Property Right, was not through well legal harmonization. Pancasila Aspiration, the adjustment with the Pancasila legal principles and Constitution of 1945 and social reality of Indonesia also have not accomodated well, eventhough there was a chace opened by TRIPs for that.

18 See further O.K. Saidin, 2013, Transplantasi Hukum Asing ke dalam Undang-Undang Hak Cipta Nasional dan Penerapannya terhadap Perlindungan Karya Sinematografi (Studi Kasus tentang Dinamika Politik Hukum dari Auteurswet 1912 ke TRIPs Agreement 1994), Disertasi, Pascasarjana USU, Medan. 
growing like mushrooms in the wilderness, not only white, but also red, yellow, orange and some even black. Science, art and literature have been growing massively and to some extent they come in different colors and nuances. Neverthless, the governing law has flourished linearly, according to the mind of the "West", namely a materialistic and liberal deeply permeating into the Eastern Hemisphere. The Agreement on Trade Related Aspects of Intellectual Property Rights (TRIPs) as a legal product that is full of Western color that is liberal and individualistic as well as materialistic has been permeating into the Eastern Hemisphere through ratification, and then the East who participated in the convention members, must adapt its Intellectual Property Rights (including its Copyright) with the demands imposed by the Agreement on Trade Related Aspects of Intellectual Property Rights (TRIPs) as a legal product that was born from and by the dominance of the Western civilization so called as the General Agreement on Tariffs and Trade (GATT) 1994/ World Trade Organization (WTO). ${ }^{19}$

This has been one of the economic globalization impacts - an impact of economic globalization that eventually contribute an impact to the Indonesian political polcies, which in turn to have an impact on legal substances of the Indonesian Copyright Law, one of which is the protection of cinematographic works.

The Indonesian puppet show tradition, which are aired from one party to another, from puppeteer to another, from sinden to another, and played in almost the same way and story, has in fact formed a culture of law, that there has not been any act of infringement committed in such act. However, with the Rome Convention which introduces the 'Neighbouring Rights', the broadcast rights, or making use use of broadcast of others, without prior permission is regarded as a violation of the rights of legal acts that may also be subject to royalty payments and such a broadcast shall have prior written consent of right holders. Factors related to legal culture is seemingly still to be given special attention in further studies. Repositioning the Pancasila and the Constitution of the Republic of Indonesia of 1945, as well as looking at The Original Paradigmative Values of Indonesian Cultural and Society may well be the the basis and direction for the political choice of Indonesian law in the future, so that Indonesian law that is born through the transplant process may well result in legal norms that "think globally, commit Nationally and locally." Thus, Indonesian law transplant of Copyright originating from foreign law (whether originally derived from the law of the Dutch Colonial and is finally adjusted to the TRIPs Agreement), all comes down to the overarching power politically along with various powers that exist in the midst of society. The dynamics of the political history of the national copyrights law making, though left no records and/or scientifically documented, the results can be strongly felt in the histroical scene of its implementation in this beloved Indonesia. What has been our hope is how to harmonize the produced laws upon the interests of Indonesia, without having to hold us to participate in the arena (economic and political), in which the law is as one its instruments.

Re-interweaving the interests of national law to be tailored to the demands of globalization (ratification of TRIPs Agreement), is hopefully expected to give birth to the concept of copyright law that commits Nationally, think globally and act locally. Revisiting and backtracking the course of history transplant of foreign law into the Indonesia copyright law, revealing the ideologicalphilosophical substance, reopening political background that characterizes the notion of legal transplant process done when the law was made, explaining numerous failures already occurred in its implementation (its law enforcement) in order to

\footnotetext{
19 We are in way to blame "the West" in their efforts to unify the vision and vision of the world economy through global regulation of the General Agreement on Tariff and Trade (GATT) 1994/World Trade Organization (WTO. However, this is part of political and historical lessons learnt for Indonesia, that is still so frozen in a to understand the importance of defending its entity as a natio; about the importance of defending the original paradigmatic of Indonesian values cultural and society, the importance of defending the nation's ideology - the Pancasila as chosen by the founding fathers, which serves as the main source of living values of nation and being a state, as well as the source of laws.
} 
repair the failures, so that everything becomes clear and bright may well deliver this study a model of the future development of Indonesian law should the country is going to use the process of transplant of foreign law in its legal policy at a later date, all of it is an important reason why this research needs to be further done.

\section{Conclusion}

Referring to the deliberations above, there are at least six important major points of law as a political bid for Indonesia, in the future, so that the laws being made in this country have not only been standardized, but in its application, it can be "responsive" (not frozen) in addressing the demands of civilization Indonesia, but also still exist in addressing global demand.

First, The Originally Paradigmatic Values of Indonesian Culture and Society, which always fails to be understood, formulated and agreed upon should be brave to be placed - not only formulated in such a rigidity and even in a death just like a postulate and theory - but further it should be brave to leave a while the scientific methodology or the way of logocentric thinking, and/or to refer to legal methodology model " old-fashined normative merely", for this way will certaintly fail at the very first step (basic policy) in incorporating some normative principles, which will be followed by the second failure (policy enactment), when the legal norms are dully implemented.

Second, the development of Indonesian law is a political process that never stops of being alienated from the behavior of legal culture or "the law procurement", as it occurs in all ethnic cultures in the archipelago since thousands of years ago. When such a process is standardized in the theory of law or legal concepts, in fact it is not only standardized but also be frozen.

Third, the law of Indonesia - as a consequence above is produced, developed and transmitted neither through material artefacts, among others, needed by researchers, nor through "behavior" to be "story". At this level, legal products generated is more verbal (not written) - through legal discovery or reference to the Anglo-Saxon tradition - rather than written law - the written law only regulates the basics - as it is known to the people of India, in the early christian era.

Fourth, regardless of written legal culture (codification and unification) to have increased refering to the tradition of continental Europe - due to the need of modern law - the cultural practices of verbal legal culture are still strongly prevailing in almost all parts of the country. This makes Indonesian legal product is communal and collective in nature - rather than personal/individual as occurs in Europe (Western). Consequently, the laws in this country will have its ultimate meaning and function when it is successfully signified and functioned by more people/parties. Anyway, a legal product shall have to be social, in its nature.

Fifth, in the tradition of Indonesian law (customary law), human being can not be legally constituted without incorporating their relations with the surrounding communities. The applicability of the law is determined by the place in which it is imposed.

Sixth, judges, police, prosecutors and the whole apparatus of law enforcers will gain such a recognition of position, so as the dignity and status, when they become primary actors (the inventor of law), in its process and related impacts. It is at this juncture, a leader and is also a ranking officer serving as legal enforcer (leader) may well be born.

\section{REFERENCES}

\section{A. Books}

Budiyoni, Tri, 2009, Transplantasi Hukum Harmonisasi dan Potensi Benturan Studi Transplantasi Doktrin yang Dikembangkan dari Tradisi Common Law pada UU PT, Griya Media, Salatiga.

Cooter, Robert dan Thomas Ulen, 1997, Law and Economics, Wesley Educational Publishers 
Inc., California.

Ganguli, Prabuddha, 2001, Intellectual Property

Rights Unleashing the Knowledge Economy,

Tata McGraw-Hill Publishing Company

Limited, New Delhi.

Hazairin, 1985, Tujuh Serangkai tentang Hukum,

Bina Aksara, Jakarta.

Irawan, Candra, 2011, Politik Hukum Hak

Kekayaan Intelektual Indonesia, Mandar

Maju, Bandung.

Laski, Harold J., 2010, Studies in Law and Politics,

Transaction Publisher, London.

Lubis, M. Solly, 2011, Manajemen Strategis

Pembangunan Hukum, Mandar Maju,

Bandung. , 2002, Sistem Nasional, Mandar Maju,

Bandung.

, 2011, Serba-Serbi Politik \& Hukum,

Sofmedia, Jakarta.

Mahfud, Moh. M.D., 2009, Politik Hukum di

Indonesia, Rajawali Pers, Jakarta.

Orucu, Esin, 2004, The Enigma of Comparative

Law, Martinus Nijhoff Publishers, Leiden/

Boston.

Elspeth Attwooll \& Sean Coyle, 1996, Studies in

Legal Systems: Mixed and Mixing, Kluwer

Law International, London/Boston.

Posner, Eric A., 2000, Law and Economics, Foundation Press, New York.

Rahardjo, Satjipto, 2009, Negara Hukum yang Membahagiakan Rakyatnya, Genta $\mathrm{Pu}-$ blishing, Jakarta. , 2009, Hukum Progrresif Sebuah Sintesa Hukum Indonesia, Genta Publishing, Jakarta. 2009, Membangun dan Merombak Hukum Indonesia Sebuah Pendekatan Lintas Disiplin, Genta Publishing, Yogyakarta.

Saidin, O.K., 2013, Aspek Hukum Hak Kekayaan Intelektual (Intellectual Property Rights), RajaGrafindo Persada, Jakarta.
Seidman, Ann dan Robert B. Seidman, 1994, State and Law in The Development Process Problem-Solving and Institutional Change in the Third World, St. Martin's Press, New York.

Seidman, Robert B., 1978, The State, Law and Development, St. Martin's Press, New York.

Stone, Julius, 1983, Legal Change Essays in Honour of Julius Stone, Blackshield, Butterworths Pty Limited, Australia.

Thalib, Sajuti, 1987, Politik Hukum Baru Mengenai Kedudukan dan Peranan Hukum Islam dalam Pembinaan Hukum Nasional, Bina Cipta, Bandung.

Wahjono, Padmo, 1983, Indonesia Negara Berdasarkan Atas Hukum, Ghalia Indonesia, Jakarta.

Watson, Alan, 1974, Legal Transplants an Approach to Comparative Law, Scottish Academic Press, America. , 2006, Legal Transplants and European Private Law, University of Belgrade School of Law, Pravni Fakultet, Belgrade.

Widjaja, Gunawan, 2008, Transplantasi Trusts dalam KUH Perdata, KUHD dan UndangUndang Pasar Modal Indonesia, Rajawali, Jakarta.

\section{B. Artikel Jurnal}

Juwana, Hikmahanto, "Politik Hukum UndangUndang Bidang Hukum Ekonomi di Indonesia”, Jurnal Hukum, Vol. 01, No. 1, 2005.

\section{Hasil Penelitian/Disertasi}

Saidin, OK, Transplantasi Hukum Asing ke dalam Undang-Undang Hak Cipta Nasional dan Penerapannya terhadap Perlindungan Karya Sinematografi (Studi Kasus tentang Dinamika Politik Hukum dari Auteurswet 1912 ke TRIPs Agreement 1994), Disertasi, Pascasarjana USU, Medan, 2013. 